\title{
Genetic variations of follicle stimulating hormone receptor are associated with polycystic ovary syndrome
}

\author{
BON-HEE GU, JUNG-MI PARK and KWANG-HYUN BAEK \\ Department of Biomedical Science, Fertility Center, CHA University, CHA General Hospital, Seoul 135-081, Korea
}

Received February 10, 2010; Accepted April 9, 2010

DOI: 10.3892/ijmm_00000441

\begin{abstract}
Polycystic ovary syndrome (PCOS) is an endocrine disorder and the criteria are specified by hyperandrogenism, oligomenorrhea or amenorrhea and polycystic ovary morphology. Follicle stimulating hormone (FSH) has effects on oogenesis and follicle development. Several polymorphisms of FSH receptor $(F S H R)$ are related to primary amenorrhea, hypoplastic ovary, and high serum levels of FSH. Thus, an increase in FSH level leads to follicle maturation and proliferation of granulosa cells. The aim of this study was to determine whether Ser680Asn and Ala307Thr polymorphisms of FSHR were associated with the clinical features of PCOS in a Korean population. PCOS patients $(n=235)$ and control subjects $(n=128)$ in the reproductive age were recruited from the Fertility Center of CHA General Hospital in Seoul, Korea. For Ser680Asn and Ala307Thr polymorphisms in FSHR, frequency of respective genotypes was measured and statistical analysis was performed. Haplotype analysis between Ser680Asn and Ala307Thr was also performed. We found that the Ser680Asn of FSHR is associated with PCOS $(p=0.0195, O R=1.66)$. However, in case of Ala307Thr, the variant is negligible and is not associated with PCOS ( $p=0.6963, \mathrm{OR}=1.08)$. In haplotype analysis, Ser680Asn and Ala307Thr polymorphisms are not related with PCOS. Consequently, the Ser680Asn polymorphism of FSHR might significantly affect PCOS patients, separately from the Ala307Thr polymorphism.
\end{abstract}

\section{Introduction}

Polycystic ovary syndrome (PCOS) is characterized by hyperandrogenism, insulin resistance, obesity, and anovulatory infertility. About 4-12\% of women within reproductive age are affected by PCOS $(1,2)$. It has been reported that $\sim 4.9 \%$ of

Correspondence to: Dr Kwang-Hyun Baek, Department of Biomedical Science, CHA University, CHA General Hospital, 606-16 Yeoksam 1-Dong, Gangnam-Gu, Seoul 135-081, Korea E-mail: baek@cha.ac.kr

Key words: folliculogenesis, insulin resistance, obesity, restriction fragment length polymorphism, single nucleotide polymorphisms female college students in Korea have PCOS (3). In 2003, the European Society of Human Reproduction and Embryology (ESHRE) and the American Society for Reproductive Medicine (ASRM) specified hyperandrogenism, oligomenorrhea or amenorrhea and polycystic ovary morphology under the criteria of PCOS (4). The dominant features of many PCOS patients include obesity and abdominal adiposity by the occurrence of insulin resistance and/or hyperinsulinemia (5). The increase of insulin level stimulates the sensitivity of granulosa cells to release follicle stimulating hormone ( $\mathrm{FSH})$, resulting in the growth of follicle cysts and regulation of steroidogenesis in the ovary. FSH plays a central role in the control of oogenesis, follicle development and gametogenesis. Thus, increase in FSH level leads to follicle maturation and proliferation of granulosa cells $(6,7)$.

Follicle stimulating hormone receptor (FSHR) is located both in Sertoli cells of the testis and granulosa cells of the ovaries $(8,9)$. FSHR acts by binding to the subgroup of G-protein coupled receptor $(10,11)$. The FSHR is divided by the intracellular domain, transmembrane region, and extracellular domain which consist of ten exons and nine introns at chromosome 2p21 $(6,7,12)$. In addition, mutations in FSHR can lead to arrest of follicle development at several phases of growth $(6,7)$. There is a number of genetic variants in the FSHR that have an effect on the phenotype. These effects include variable development of secondary sex characteristics, primary amenorrhea, hypoplastic ovary, and high serum levels of FSH (13-16). Prevalent polymorphisms of FSHR are found within exon 10 at position 307 and 680 . Position 307 is occupied by either alanine (Ala) or threonine (Thr) and position 680 is occupied by either serine (Ser) or asparagine (Asn) in the intracellular domain of the protein (12). However, some research groups have reported the occurrence of the same polymorphisms located in different amino acid positions, resulting in different allele genotyping $(7,17)$. Other research groups have reported that the substituted nucleotide is different for the same polymorphism, and consequently an amino acid is differentially changed (7,17-19). For example, Ala307Thr is mentioned as Thr307Ala. Furthermore, polymorphisms at 307 and 680 codon of FSHR have shown diverse phenotypes among different ethnic groups and diseases (20-23).

The aim of our study was to compare single nucleotide polymorphisms (SNPs) in FSHR in Korean PCOS patients and other ethnic populations, and to apply our experimental observations and scientific knowledge for clinical manifestation in patients with PCOS. 
Table I. Clinical and biochemical characteristics between PCOS patients $(n=235)$ and normal controls $(n=128)$.

\begin{tabular}{|c|c|c|}
\hline & PCOS patient group & Control group \\
\hline No. & 235 & 128 \\
\hline Body Mass Index $\left(\mathrm{kg} / \mathrm{m}^{2}\right)$ & $22.96 \pm 3.86 \quad(16.36-37.32)$ & $20.95 \pm 2.49 \quad(16.40-28.65)$ \\
\hline Waist/hip ratio (WHR) & $0.82 \pm 0.06 \quad(0.69-0.95)$ & $(0.70-0.91)$ \\
\hline $\begin{array}{l}\text { Hyperandrogenism and } \\
\text { oligomenorrhea or amenorrhea }\end{array}$ & $(13.30 \%)$ & $(0.00 \%)$ \\
\hline $\begin{array}{l}\text { Hyperandrogenism } \\
\text { and polycystic ovaries }\end{array}$ & $(9.44 \%)$ & $(0.00 \%)$ \\
\hline $\begin{array}{l}\text { Oligomenorrhea or amenorrhea } \\
\text { and polycystic ovaries }\end{array}$ & $(67.82 \%)$ & $(0.00 \%)$ \\
\hline $\begin{array}{l}\text { Hyperandrogenism, oligomenorrha } \\
\text { or amenorrhea and polycystic ovaries }\end{array}$ & $(9.44 \%)$ & $(0.00 \%)$ \\
\hline FSH levels $(\mathrm{mIU} / \mathrm{ml})$ & $(3.20-8.49)$ & $(3.00-11.50)$ \\
\hline LH levels (mIU/ml) & $\begin{array}{c}6.05 \pm 3.47 \quad(1.00-17.02) \\
(\mathrm{p}<0.001)\end{array}$ & $(1.00-7.10)$ \\
\hline $\mathrm{E}_{2}$ levels $(\mathrm{pg} / \mathrm{ml})$ & $33.18 \pm 13.01 \quad(9.10-81.40)$ & $36.92 \pm 33.49 \quad(5.00-219.90)$ \\
\hline PRL levels (pg/ml) & $10.62 \pm 3.06 \quad(2.30-20.90)$ & $13.14 \pm 7.32 \quad(4.10-46.40)$ \\
\hline TSH levels $(\mu \mathrm{IU} / \mathrm{ml})$ & $2.09 \pm 1.21 \quad(0.46-5.47)$ & $1.89 \pm 0.96 \quad(0.03-4.06)$ \\
\hline DHEA-S levels $(\mu \mathrm{g} / \mathrm{dl})$ & $\begin{array}{c}194.07 \pm 75.50(45.30-377.20) \\
(p=0.011)\end{array}$ & $153.01 \pm 56.40(67.20-257.40)$ \\
\hline Testosterone levels $(\mathrm{mg} / \mathrm{ml})$ & $\begin{array}{c}0.38 \pm 0.20 \quad(0.06-0.86) \\
(\mathrm{p}<0.001)\end{array}$ & $(0.01-0.54)$ \\
\hline
\end{tabular}

\section{Materials and methods}

Subjects. All subjects were recruited from the Fertility Center of CHA General Hospital in Seoul, Korea. The present study evaluated 235 patients with PCOS and 128 normal Korean females. Patients were selected based on the revised diagnostic criteria announced in 2003 ASRM/ESHRE Rotterdam consensus (4). Clinical and biochemical characteristics of patients with PCOS and controls are estimated in Table I. Healthy status was determined by their medical history, physical and pelvic examination, as well as complete blood chemistry. For the diagnostic criteria of PCOS, oligomenorrhea was defined as a reduction in the frequency of menses with intervals between 40 days and 6 months and hyperandrogenism was defined as serum testosterone $(\mathrm{T})>0.6 \mathrm{ng} / \mathrm{ml}$ and/or serum DHEA-S $\geq 300 \mu \mathrm{g} / \mathrm{dl}(12,19)$. Consent to used documented data was obtained from all examined patients.

Blood samples were collected from patients with PCOS and normal controls. The hormone and glucose levels including plasma FSH, LH, E 2 , PRL, TSH, DHEA-S, and T were estimated and analyzed to discriminate the changes between samples from patients and normal controls.

Restriction fragment length polymorphism (RFLP) analysis. Blood samples were collected in tubes containing EDTA as an anticoagulant and stored at $4^{\circ} \mathrm{C}$ until use. Genomic DNA was obtained from the blood samples of patients with PCOS and a healthy group of Korean females. Extraction of genomic DNA was performed according to the manufacturer's instructions (Gentra, Minneapolis, MA, USA). An SNP study with human blood samples was approved by the Institutional Review Board (IRB).
FSHR genotyping. Two polymorphisms of FSHR, Ala307Thr and Ser680Asn, are located in 919 and 2,039 among the cDNA positions, respectively (Accession No. NM_000145). The presence of the Ser680Asn of FSHR was detected by RFLP analysis. The Ser680Asn of FSHR was PCR amplified using 5'-TTT GTG GTC ATC TGT GGC TGC-3' forward primer and 5'-CAA AGG CAA GGA CTG AAT TAT CAT T-3' reverse primer in a total volume of $25 \mu \mathrm{l}$. Cycling parameters used for conducting PCR amplification was at $94^{\circ} \mathrm{C}$ for $5 \mathrm{~min}$, $94^{\circ} \mathrm{C}$ for $30 \mathrm{sec}, 58^{\circ} \mathrm{C}$ for $30 \mathrm{sec}, 72^{\circ} \mathrm{C}$ for $30 \mathrm{sec}$, and $72^{\circ} \mathrm{C}$ for $5 \mathrm{~min}$. The PCR products were purified by PCR purification kit (AccuPrep, Bioneer, Daejeon, Korea) and digested with Bsr I (New England Biolabs, Beverly, MA, USA) for $4 \mathrm{~h}$ at $65^{\circ} \mathrm{C}$. DNA fragments were electrophoresed on a $2 \%$ agarose gel containing ethidium bromide and visualized by ultraviolet transilluminator. The $B s r$ I restricts at a site containing the $G$ allele in purified PCR products. From the $B s r$ I digestion profile, we obtained a single 520-bp band indicating homozygosity for $A$ allele, and the presence of 413- and 107-bp bands confers homozygosity for $G$ allele, and together bands of 520, 413, and $107 \mathrm{bp}$ correspond to heterozygosity for the $A$ and $G$ alleles.

The Ala307Thr of FSHR was detected by RFLP analysis. A 657 bp fragment of FSHR was amplified by PCR using a set of primers, 5'-TCT GAG CTT CAT CCA ATT TGC A-3' and 5'-GGG AAA GAG GGC AGC TGC AA-3'. Cycling parameters used to perform PCR amplification were at $94^{\circ} \mathrm{C}$ for $5 \mathrm{~min}, 94^{\circ} \mathrm{C}$ for $1 \mathrm{~min}, 58^{\circ} \mathrm{C}$ for $1 \mathrm{~min}, 72^{\circ} \mathrm{C}$ for $1 \mathrm{~min}$, and $72^{\circ} \mathrm{C}$ for $5 \mathrm{~min}$. Amplified PCR products were purified using PCR purification kit (AccuPrep, Bioneer, Daejeon, Korea), and purified products were used as a template to re-amplify using another set of primers, 5'-AAG AAG TTG ATT ATA 

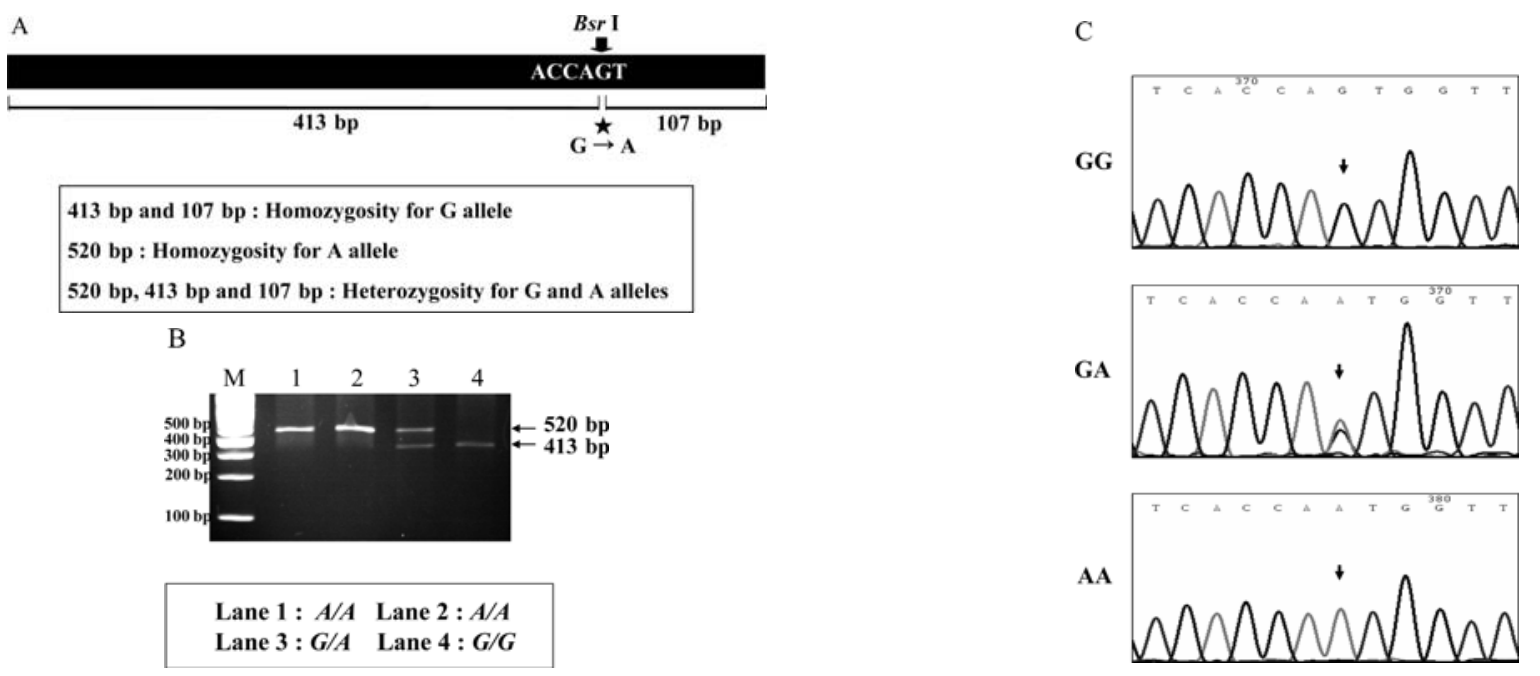

Figure 1. (A) RFLP analysis for Ser680Asn polymorphism. The Ser680Asn variant was digested by Bsr I for genotyping. (B) In RFLP analysis, the sizes of homozygote $G G$ are 413 and 107 bp. $A A$ genotype shows a 520-bp band. The sizes of heterozygote GA genotype are 520, 413, and 107 bp. (C) Sequence analyses of the Ser680Asn gene polymorphism using a forward primer.

TGC CTC AG-3' and 5'-GTA GAT TCC AAT GCA GAG ATC A-3'. For the second PCR, cycling parameters used to perform PCR amplification were at $94^{\circ} \mathrm{C}$ for $5 \mathrm{~min}, 94^{\circ} \mathrm{C}$ for $1 \mathrm{~min}, 55^{\circ} \mathrm{C}$ for $1 \mathrm{~min}, 72^{\circ} \mathrm{C}$ for $1 \mathrm{~min}$, and $72^{\circ} \mathrm{C}$ for $5 \mathrm{~min}$. The second PCR products were also purified using the PCR purification kit. Bsu36 I (New England Biolabs, Beverly, MA, USA) restricts at a site containing the $G$ allele in purified PCR products. A mismatched nucleotide, $G \rightarrow A$, was observed in the samples and was not digested by a restriction enzyme, Bsu36 I. A 328 bp for $G G$ genotype, two bands, 328 and 364 bp for $G A$ genotype, and 364-bp for $A A$ genotype were revealed. However, a 36-bp fragment was detected on $2.5 \%$ gel because of its small size. To verify genotyping results in RFLP, we performed sequencing analysis using amplified PCR products.

Data and statistical analysis. Statistical analysis was carried out using Hap Analysis and SAS. 9.1 (2006) (24) Logistic regression and $\chi^{2}$ tests were used to analyze the association between PCOS and healthy controls. A p $<0.05$ value was considered statistically significant. Haploview 4.1 software (www.broad.mit.edu/mpg/haploview) was used for casecontrol haplotype analysis. Linkage disequilibrium (LD) was tested by the $\chi^{2}$ test, and a number of permutations was fixed at 100,000 in the permutation tests. In haplotype analysis, D' value was computed at 1.

\section{Results}

We diagnosed the samples obtained from normal and PCOS patients in Korean female subjects, based on the diagnostic criteria announced in the 2003 ASRM/ESHRE Rotterdam consensus (4). Table I shows clinical and biochemical profiles of PCOS patients and normal controls. We ascertained that the level of LH, testosterone, and DHEA-S was higher in PCOS patients compared with normal controls. In addition, Table I displays the features of PCOS symptoms, including polycystic ovaries, oligomenorrhea or amenorrhea, and hyperandrogenism. We distinguished between PCOS and normal control groups based on these specified criteria.
To investigate the frequency of genotype in FSHR, we used RFLP analysis as a tool. First, we performed RFLP analysis for Ser680Asn of FSHR. Genetic variations of Ser680Asn revealed three genotypes, $G G, G A$, and $A A$ (Fig. 1). A homozygote genotype of $A A$ was observed in $58.72 \%$ of PCOS patients, and with a higher frequency of $71.88 \%$ in the control group (Table II). In contrast, the frequency for the heterozygote $G A$ genotype and homozygote of $G G$ genotype was higher in PCOS patients $(G A=38.72 \%$ and $G G=2.56 \%)$ than in the control group ( $G A=27.34 \%$ and $G G=0.78 \%$ ) (Table II). Using the HapAnalyzer, we found that the Ser680Asn of FSHR is associated with PCOS patients ( $\mathrm{p}$-value $=0.0195, \mathrm{OR}=1.66$ ). The co-dominant and dominant frequencies of Ser680Asn were significantly associated with PCOS patients $(p=0.0103$ and $\mathrm{OR}=1.77$ for co-dominant frequency, $\mathrm{p}=0.0135$ and $\mathrm{OR}=1.80$ for dominant frequency) (Table II). Consequently, the Ser680Asn polymorphism of FSHR might significantly affect females with PCOS.

Ala307Thr variant has three genotypes $(G G, G A$, and $A A)$ (Fig. 2). Homozygote $G G, A A$ and heterozygote of $G A$ genotype were found to be similar in PCOS patients $(G G=16.17$, $G A=49.36, A A=34.47 \%)$ and the control group $(G G=17.19$, $G A=43.75, A A=39.06 \%$ ) (Table II). Using the HapAnalyzer, we found that the influence of Ala307Thr variant was negligible and not associated with PCOS $(p=0.6963$, $\mathrm{OR}=1.08$ ) (Table II).

In order to identify the relation between the two polymorphisms, we analyzed haplotypes between Ser680Asn and Ala307Thr of FSHR (Table III). In haplotype and permutation tests, only $G-G$ (Ser680Asn and Ala307Thr) was significantly associated $(\mathrm{P}<0.05)$. Furthermore, the haplotype frequency of $G-G$ was revealed in PCOS patients, but not in healthy control patients.

\section{Discussion}

PCOS is a complex genetic disease affected by multiple metabolism factors and its symptoms vary from obesity, to insulin resistance, to glucose intolerance, to dyslipidemia. As a 
Table II. Frequency of Ser680Asn and Ala307Thr polymorphisms of the FSHR gene in PCOS patient group (n=235) and normal control group $(\mathrm{n}=128)$.

\begin{tabular}{|c|c|c|c|c|c|c|c|c|c|}
\hline \multirow[t]{2}{*}{ Loci } & \multirow[t]{2}{*}{ Genotype } & \multirow[t]{2}{*}{ Case (PCOS) } & \multirow[t]{2}{*}{ Control } & \multicolumn{2}{|c|}{ Co-dominant } & \multicolumn{2}{|c|}{ Dominant } & \multicolumn{2}{|c|}{ Recessive } \\
\hline & & & & OR $(95 \% \mathrm{CI})$ & $\mathrm{P}$ & OR $(95 \% \mathrm{CI})$ & $\mathrm{P}$ & OR $(95 \% \mathrm{CI})$ & $\mathrm{P}$ \\
\hline \multirow[t]{4}{*}{680} & GG & $6(2.56 \%)$ & $1(0.78 \%)$ & \multirow[t]{4}{*}{$\begin{array}{c}1.77 \\
(1.14-2.74)\end{array}$} & \multirow[t]{3}{*}{0.0103} & \multirow[t]{3}{*}{$\begin{array}{c}1.80 \\
(1.13-2.86)\end{array}$} & \multirow[t]{3}{*}{0.0135} & \multirow[t]{4}{*}{$\begin{array}{c}3.33 \\
(0.40-27.95)\end{array}$} & \multirow[t]{4}{*}{0.2682} \\
\hline & GA & $91(38.72 \%)$ & $35(27.34 \%)$ & & & & & & \\
\hline & AA & $138(58.72 \%)$ & $92(71.88 \%)$ & & & & & & \\
\hline & total & 235 & 128 & & \multicolumn{3}{|c|}{ OR $(95 \% C I)=1.66(1.10-2.51) ; p=0.0195$} & & \\
\hline \multirow[t]{4}{*}{307} & GG & $38(16.17 \%)$ & $22(17.19 \%)$ & \multirow[t]{4}{*}{$\begin{array}{c}1.08 \\
(0.76-1.47)\end{array}$} & \multirow[t]{3}{*}{0.6412} & \multirow[t]{3}{*}{$\begin{array}{c}1.22 \\
(0.78-1.90)\end{array}$} & \multirow[t]{3}{*}{0.3841} & \multirow[t]{3}{*}{$\begin{array}{c}0.93 \\
(0.52-1.65)\end{array}$} & \multirow[t]{4}{*}{0.8031} \\
\hline & GA & $116(49.36 \%)$ & $56(43.75 \%)$ & & & & & & \\
\hline & AA & $81(34.47 \%)$ & $50(39.06 \%)$ & & & & & & \\
\hline & total & 235 & 128 & & \multicolumn{4}{|c|}{ OR $(95 \% \mathrm{CI})=1.08(0.76-1.47) ; \mathrm{p}=0.6963$} & \\
\hline
\end{tabular}
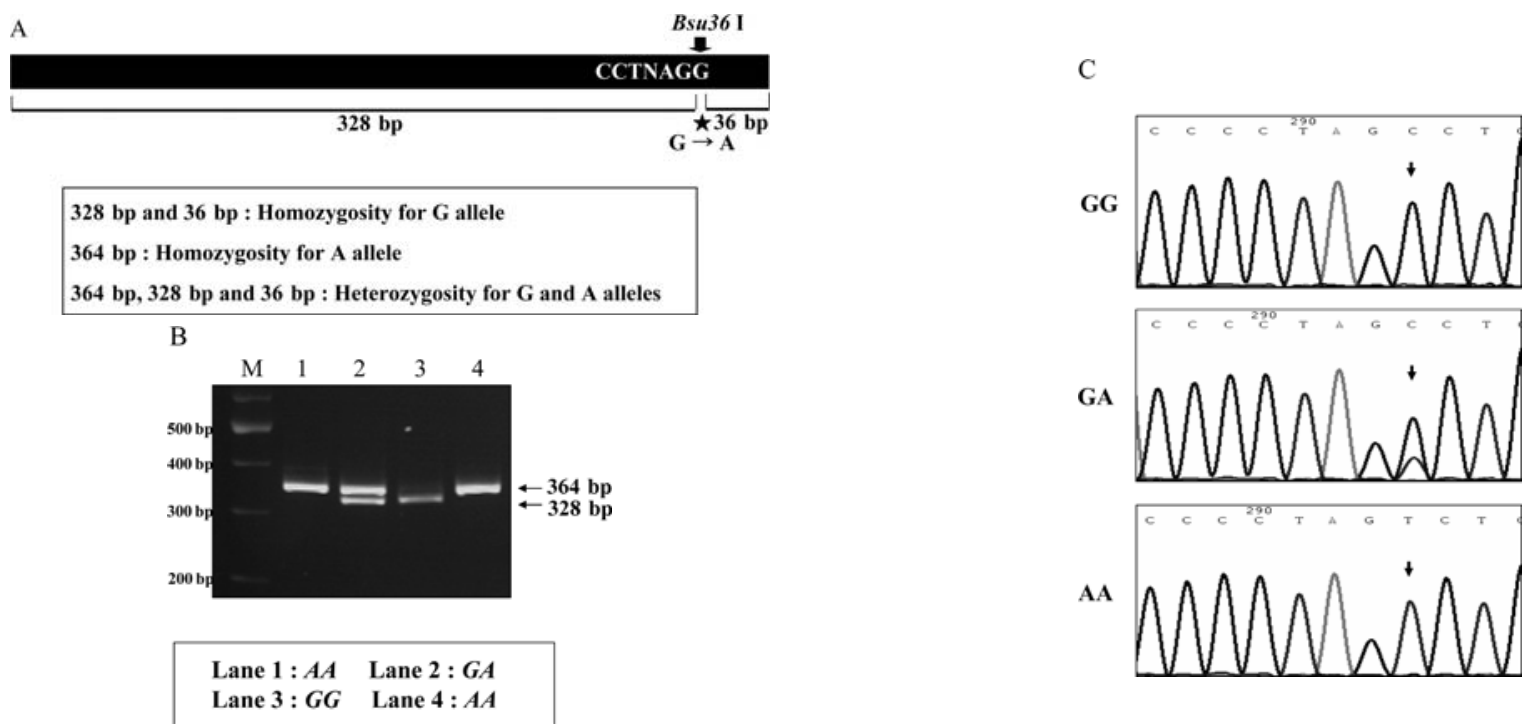

Figure 2. (A) RFLP analysis for Ala307Thr polymorphism. The Ala307Thr variant was digested by Bsu36 I for genotyping. (B) In RFLP analysis, the sizes of homozygote $A A$ and $G G$ genotypes are 364 and 328 bp, respectively. The size of heterozygote $G A$ genotype are 364,328 , and 36 bp. However, a 36 bp band has run off on the $2.5 \%$ gel. (C) Sequence analyses of the Ala307Thr gene polymorphism was carried out using a reverse primer.

Table III. Haplotype analysis between Ser680Asn and Ala307Thr of the FSHR gene.

\begin{tabular}{|c|c|c|c|c|c|}
\hline \multirow{2}{*}{$\begin{array}{l}\text { Haplotype } \\
\text { (Ser680Asn- } \\
\text { Ala307Thr) }\end{array}$} & \multicolumn{2}{|c|}{ Frequency } & \multirow[t]{2}{*}{$\mathrm{P}$} & \multicolumn{2}{|c|}{ Permutation tests } \\
\hline & $\begin{array}{c}\text { Case } \\
\text { (PCOS) }\end{array}$ & Control & & $\mathrm{P}$ & $\chi^{2}$ \\
\hline A-A & 0.419 & 0.469 & 0.197 & 0.488 & 1.658 \\
\hline A-G & 0.362 & 0.391 & 0.441 & 0.851 & 0.594 \\
\hline G-A & 0.172 & 0.141 & 0.266 & 0.624 & 1.233 \\
\hline G-G & 0.047 & 0.000 & $<0.001$ & 0.004 & 12.357 \\
\hline
\end{tabular}

complex genetic disease, a number of studies have been performed on multiple SNPs such as GnRH and CYP17 to identify the pathogenesis of PCOS (25-27). For example, the
Fat mass and obesity associated (FTO) gene in the glucose intolerance is strongly related to PCOS $(28,29)$. It has also been shown that the insulin receptor substrate-1 (IRS-1) gene, which regulates insulin resistance, has an influential role in PCOS (30). In this study, we have demonstrated the possibility of pathophysiological treatment for the aberration of FSHR, which regulates folliculogenesis, one of the diverse metabolism pathways.

In women of a reproductive age, FSH is an important hormone required for the developmental follicle, oocyte maturation, and regulation of steroidogenesis in the ovaries. In addition, FSHR is involved in the regulation of the FSH level and it belongs to G-protein coupled receptors, causing phosphorylation of target proteins and adenylate cyclase (31). The regulation of FSH level is controlled by FSHR, and it is known that aberrant FSHR affects ovary and folliculogenesis. Previously, it has been reported that two polymorphisms of 
FSHR, Asn567Asp and Thr499Ala, have led to elevated levels of thyrotopin (TSH) (32). Orio et al have reported the relationship between polymorphisms of FSHR and PCOS in Italian females (11). However, significant changes were not reported in various polymorphisms of FSHR including Ala307Thr and Ser680Asn in PCOS patients (11). Similar observations were reported in Chinese Singapore females with PCOS, having polymorphisms in Ala307Thr and Ser680Asn of FSHR (19). In contrast, two mutant polymorphisms of FSHR have myriad results in several ethnic populations $(7,12,19,20)$.

In this study, we showed that a polymorphism of Ala307Thr in FSHR was not responsible for any significant pathophysiological changes. Interestingly, the Ser680Asn polymorphism in FSHR appeared as a causative factor among PCOS patients in a Korean population. Since the association of Ser680Asn in FSHR was identified as a potential factor for pathophysiological changes, we suggest further clinical diagnosis of PCOS patients.

Our results have shown that the level of LH in PCOS patients was 2-fold higher than that of the control group, and the DHEA-S and testosterone levels showed a slightly high expression in the PCOS patient group (Table I). Collectively, our study suggests that the Ser680Asn polymorphism in FSHR, not Ala307Thr, leads to infertility and aberrant folliculogenesis in patients with PCOS. However, several polymorphisms in FSHR correlated with PCOS are not yet clearly understood. To elucidate the importance of SNPs in FSHR in PCOS patients, further investigation with a large population of PCOS patients derived from different ethnic backgrounds is required. It should also be considered that the factors responsible for the association of PCOS with several other disorders are essential for clinical diagnosis among PCOS patients.

\section{Acknowledgements}

We thank the members of the Fertility Center at CHA University and CHA General Hospital for support. We also thank Drs Sadia Abbasi and Yong-Soo Kim at the National Institutes of Health (Maryland, USA) for their critical comments on this manuscript. This study was supported by a grant from Korea Health 21 R\&D Project, Ministry of Health, Welfare and Family Affairs, Republic of Korea (01-PJ10-PG6-01GN13-0002).

\section{References}

1. Franks S: Polycystic ovary syndrome. N Engl J Med 333: 853-861, 1995

2. Wood JR, Ho CK, Nelson-Degrave VL, McAllister JM and Strauss JF 3rd: The molecular signature of polycystic ovary syndrome (PCOS) theca cells defined by gene expression profiling. J Reprod Immunol 63: 51-60, 2004.

3. Byun EK, Kim JH, Oh JY, Hong YS and Sung YA: The prevalence of polycystic ovary syndrome in college students from Seoul. J Korean Soc Endocrinol 20: 120-126, 2005.

4. The Rotterdam ESHRE/ASRM-Sponsored PCOS Consensus Workshop Group: Revised 2003 consensus on diagnostic criteria and long-term health risks related to polycystic ovary syndrome (PCOS). Hum Reprod 19: 41-47, 2004.

5. Dunaif A: Insulin resistance in women with polycystic ovary syndrome. Fertil Steril 86: S13-S14, 2006.

6. Simoni M, Gromoll J and Nieschlag E: The Follicle-stimulating hormone receptor: biochemistry, molecular biology, physiology, and pathophysiology. Endocr Rev 18: 739-773, 1997.
7. Sudo S, Kudo M, Wada S, Sato O, Hsueh AJ and Fujimoto S: Genetic and functional analyses of polymorphisms in the human FSH receptor gene. Mol Hum Reprod 8: 893-899, 2002.

8. Kwok HF, So WK, Wang Y and Ge W: Zebrafish gonadotropins and their receptors: I. Cloning and characterization of zebrafish follicle-stimulating hormone and luteinizing hormone receptors - evidence for their distinct functions in follicle development. Biol Reprod 72: 1370-1381, 2005.

9. Yamamura N, Takeishi M, Goto H, Tagami M, Mizutani T, Miyamoto K, Doi O and Kamiyoshi M: Expression of messenger RNA for gonadotropin receptor in the granulose layer during the ovulatory cycle of hens. Comp Biochem Physiol Part A Mol Integr Physiol 129: 327-337, 2001.

10. Wunsch A, Ahda Y, Banaz-Yasar F, Sonntag B, Nieschlag E, Simoni $\mathrm{M}$ and Gromoll J: Single-nucleotide polymorphisms in the promoter region influence the expression of the human folliclestimulating hormone receptor. Fertil Steril 84: 446-453, 2005.

11. Orio F Jr, Ferrarini E, Cascella T, Dimida A, Palomba S, Gianetti E, Colao A, Agretti P, Vitti P, Lombardi G, Pinchera A and Tonacchera M: Genetic analysis of the follicle stimulating hormone receptor gene in women with polycystic ovary syndrome. J Endocrinol Invest 29: 975-982, 2006.

12. Perez Mayorga M, Gromoll J, Behre HM, Gassner C, Nieshlag E and Simoni M: Ovarian response to follicle-stimulating hormone (FSH) stimulation depends on the $\mathrm{FSH}$ receptor genotype. J Clin Endocrinol Metab 85: 3365-3369, 2000.

13. Aittomaki K, Herva R, Sternman UH, Juntunen K, Ylostalo P, Hovatta $\mathrm{O}$ and de la Chapelle A: Clinical features of primary ovarian failure caused by a point mutation in the folliclestimulating hormone receptor gene. J Clin Endocrinol Metab 81: 3722-3726, 1996.

14. Aittomaki K, Lucena JL, Pakarinen P, Sistonen P, Tapanainen J, Gromoll J, Kaskikari R, Sankila EM, Lehvaslaiho, Engel AR, Nieschlag E, Huhtaniemi I and de la Chapelle A: Mutation in the follicle-stimulating hormone receptor gene causes hereditary hypergonadotropic ovarian failure. Cell 82: 959-968, 1995.

15. Meduri G, Touraine P, Beau I, Lahuna O, Desroches A, Vacher-Lavenu MC, Kuttenn F and Misrahi M: Delayed puberty and primary amenorrhea associated with a novel mutation of the human follicle-stimulating hormone receptor: clinical, histological, and molecular studies. J Clin Endocrinol Metab 88: 3491-3498, 2003.

16. Achrekar SK, Modi DN, Desai SK, Mangoli VS, Mangoli RV and Mahale SD: Follicle-stimulating hormone receptor polymorphism (Thr307Ala) is associated with variable ovarian response and ovarian hyperstimulation syndrome in Indian women. Fertil Steril 91: 432-439, 2009

17. Overbeek A, Kuijper EA, Hendriks ML, Blankenstein MA, Ketel IJ, Twisk JW, Hompes PG, Homburg R and Lambalk CB: Clomiphene citrate resistance in relation to follicle-stimulating hormone receptor Ser680Ser-polymorphism in polycystic ovary syndrome. Hum Reprod 24: 2007-2013, 2009.

18. Simoni M, Nieschlag $\mathrm{E}$ and Gromoll $\mathrm{J}$ : Isoforms and single nucleotide polymorphisms of the FSH receptor gene: implications for human reproduction. Hum Reprod Update 8: 413-421, 2002.

19. Tong Y, Liao WX, Roy AC and Ng SC: Absence of mutations in the coding-regions of follicle-stimulating hormone receptor gene in Singapore Chinese women with premature ovarian failure and polycystic ovary syndrome. Horm Metab Res 33: 221-226, 2001.

20. Conway GS, Conway E, Walker C, Hoppner W, Gromoll J and Simoni M: Mutation screening and isoform prevalence of the follicle stimulating hormone receptor gene in women with premature ovarian failure, resistant ovary syndrome and polycystic ovary syndrome. Clin Endocrinol 51: 97-99, 1995.

21. Ahda Y, Gromoll J, Wunsch A, Asatiani K, Zitzmann M, Nieschlag E and Simini M: Follicle-stimulating hormone receptor gene haplotype distribution in normozoospermic and azoospermic men. J Androl 26: 494-499, 2005.

22. Batista MC, Kohek MB, Frazzatto ES, Fragoso MC Mendonça BB and Latronico AC: Mutation analysis of the follicle-stimulating hormone receptor gene in girls with gonadotropin-independent precocious puberty resulting from autonomous cystic ovaries. Fertil Steril 73: 280-283, 2000.

23. Pengo M, Ferlin A, Arredi B, Ganz F, Selice R, Garolla A and Foresta C: FSH receptor gene polymorphisms in fertile and infertile Italian men. Reprod Biomed Online 13: 795-800, 2006.

24. Lee EJ, Oh B, Lee JY, Kimm K, Park JM and Baek KH: Association study between single nucleotide polymorphisms in the VEGF gene and polycystic ovary syndrome (PCOS). Fertil Steril 89: 1751-1759,2008. 
25. Valkenburg O, Uitterlinden AG, Piersma D, Hofman A, Themmen AP, de Jong FH, Fauser BC and Laven JS: Genetic polymorphisms of GnRH and gonadotrophic hormone receptors affect the phenotype of polycystic ovary syndrome. Hum Reprod 24: 2014-2022, 2009.

26. Unsal T, Konac E, Yesilkaya E, Yilmaz A, Bideci A, Ilke Onen H, Cinaz P and Menevse A: Genetic polymorphisms of FSHR, CYP17, CYP1A1, CAPN10, INSR, SERPINE1 genes in adolescent girls with polycystic ovary syndrome. J Assist Reprod Genet 26: 205-216, 2009.

27. Park JM, Lee EJ, Ramakrishna S, Cha DH and Baek KH Association study for single nucleotide polymorphisms in the CYP17A1 gene and polycystic ovary syndrome. Int J Mol Med 22: 249-254, 2008

28. Attaoua R, Ait El Mkadem S, Radian S, Fica S, Hanzu F, Albu A, Gheorghiu M, Coculescu M and Grigorescu F: FTO gene associates to metabolic syndrome in women with polycystic ovary syndrome. Biochem Biophys Res Commun 373: 230234,2008 .
29. Wehr E, Schweighofer N, Möller R, Giuliani A, Pieber TR and Obermayer-Pietsch B: Association of FTO gene with hyperandrogenemia and metabolic parameters in women with polycystic ovary syndrome. Metabolism 59: 575-580, 2009.

30. Villuendas G, Botella-Carretero JI, Roldan B, Sancho J, Escobar-Morreale HF and San Millan JL: Polymorphisms in the insulin receptor substrate-1 (IRS-1) gene and the insulin receptor substrate-2 (IRS-2) gene influence glucose homeostasis and body mass index in women with polycystic ovary syndrome and non-hyperandrogenic controls. Hum Reprod 20: 3184-3191, 2005.

31. Richards JS: Hormonal control of gene expression in the ovary. Endocr Rev 15: 725-751, 1994.

32. Montanelli L, Delbaere A, Di Carlo C, Nappi C, Smits G, Vassart G and Costagliola S: A mutation in the follicle-stimulating hormone receptor as a cause of familial spontaneous ovarian hyperstimulation syndrome. J Clin Endocrinol Metab 89: 1255-1258, 2004. 